\title{
Notes on Operations Online Book Selling at the Smathers Library Bookstore
}

\section{Steven B. Carrico}

In fall 2003, the Smathers Library Bookstore instituted a one-year pilot project selling surplus gift books online. This paper describes how the bookstore staff researched, prepared, and embarked on online book selling. It illustrates how the bookstore staff selected the online book selling agent, Alibris, as the Web site utilized for their online selling, and provides details in the methodology of listing books for sale in the used book market. The paper presents the responses to questions asked of staff at two other libraries selling books online, and concludes with a summary of the online sales project.

The University of Florida (UF) 1 Smathers Library's Gifts and Exchange unit is the central receiving area for incoming gift materials donated to the main and branch libraries. The Smathers Library has gift acceptance policies and procedures that are consistent with other large academic libraries, and benefit from thousands of donated books, serials, and other items each year. ${ }^{1}$ The library views gift donations as an excellent method of bolstering collections by adding items not previously held, filling gaps in periodical holdings, or replacing missing and damaged monograph titles. In fiscal year 2003-2004, the Gifts and Exchange unit received 15,678 gift items.

To better serve library donors and to improve efficiency, the Gifts and Exchange staff routinely send a library van to collect material gifts from donors on campus and in the local community. Though offering van service requires staff time and small demands on library facilities, the library realizes that collecting gift materials at a donor's office or residence improves goodwill and is an ideal way to increase donations to the library. After receipt of the donations, student assistants search the online catalog for each book and serial title, filling out slips with appropriate information to assist the gift review process. Collection managers then perform the review of the searched gift materials and select suitable new titles or replacements for missing library holdings.

As is the case with numerous libraries-whether large or small, academic, public or private-a large percentage of donated gift materials received at UF is not added to library collections. Of the 12,619 books donated to the Smathers Library in fiscal year 2003-2004, 69 percent went unselected for library collections, leaving 8,727 surplus gift books for sale stock. Consequently, unselected gifts become problematic, and libraries dread the backlash of bad publicity, angry donors, and misunderstanding that can result from disposing of surplus gift books. To counter possible negative reactions, the Smathers Library developed procedures and a policy stating that all gift materials accepted by the library become the property of the library; after collection managers review and select appropriate items from the donation, the library can sell or discard surplus gifts as needed. ${ }^{2}$ The Gifts and Exchange staff are forthright with prospective donors, bringing this policy to their attention before accepting any gifts. The staff also requests donors to read
Steve B.Carrico (stecarr@uflib.ufl.edu) is
Gifts and Exchange Librarian, University of Florida Smathers Library, Gainesville. 
and sign a receipt of donation that includes information with respect to gift disposition. ${ }^{3}$ With a clear and honest approach, most donors seem quite accepting of the library gift policy.

While granting the library the option of disposing of unneeded gifts, this policy allows the library to deal with unselected gift materials immediately after collection management review, ultimately reducing storage. Additionally, the policy entitles the library to sell surplus gifts. To better maximize the profit from the sale of the materials, the Smathers Library elected to open a bookstore to generate revenue for the book acquisition fund. ${ }^{4}$

\section{Proposal for Online Selling}

The Gifts and Exchange unit has the responsibility of managing the bookstore. From August 1999 through July 2004 , the store grossed $\$ 42,947.27$, or approximately $\$ 8,000$ per fiscal year. Based on this yearly gross income, the library considers the bookstore a success. Nevertheless, the bookstore staff themselves noted that too often finer-quality or first-edition books were selling at the standard price of three dollars. At other times, the staff watched local book dealers and online book sellers purchase large stacks of books and realized the bargain prices would convert into substantial profits for the dealers through later resales. The staff working in the store made every effort to sell specially identified items at higher prices to book dealers and collectors, as well as highlighting their availability to all bookstore customers by means of a display window and case. Among the specialty books selected from the stock were first editions, university press publications, architecture and art books, and other specialized pieces. Although these efforts were relatively successful, the staff felt that too often books with high value on the used book market continued to sell at bargain bin prices. The bookstore staff ultimately concluded that it was in the library's best interest to undertake online book selling in an effort to truly maximize revenue from the used book market.

Regardless of the plan to begin online selling, the staff did not want to detract from the existing success of the bookstore. The store not only realizes a tidy profit, its location on the first floor of the Smathers Library is an excellent promotional tool for the library development office. For these reasons, the staff aimed to maintain sales in the bookstore by not removing all the best stock for online selling. One important objective then was to endeavor to strike a balance between selling the finer books online and selling to bookstore patrons and book dealers. Because online selling would require administrative approval, the staff researched library literature and sent a small questionnaire to representatives in other libraries with online selling experience. Based on the information gathered, the staff planned to develop and submit a proposal for a one-year pilot project. A one-year window would provide the time necessary to monitor any fluctuations in online sales that might arise from academic semesters and holiday schedules. After careful weeding from unselected gifts stock, the bookstore staff collected several hundred finer-quality books to sell online. Choosing to be cautious, the staff set goals of selling twenty books a month and earning $\$ 2,500$ in online sales for the year.

\section{Literature Survey}

Several articles have detailed the methods some libraries have developed to increase profits from the sales of surplus gift and withdrawn materials. The impetus to sell the finer quality donated books through auctions is well documented, as is the subject of opening bookstores in lieu of traditional library book sales; articles dealing with libraries selling materials online are harder to find. ${ }^{5}$ Although selling used books on the Web has been occurring for several years, libraries using the Internet as a means to dispose of and profit from selling withdrawn or surplus gifts is a relatively recent development.

Articles focusing on public libraries using the online auction site eBay to sell materials in lieu of traditional book sales include Schenker's "Book Sale Adds Internet." Baxter's "Your Discards May Be Somebody's Treasure," serves as an ideal first reading venture into the online book business. ${ }^{7}$ Baxter, an acquisitions librarian, reported how her public library makes use of eBay to sell surplus gift and withdrawn books. She explained how online auctions work and how to register with eBay as a seller, then offered excellent tips and advice on pricing and book descriptions for the items placed on sale.

From the perspective of a public library board member and library friend, Hill wrote "Selling Withdrawn and Gift Books on eBay: Does It Make Sense?" This article reported how the Friends of Los Gatos Public Library use eBay to auction donated materials. Hill described the procedures the volunteers use as they sort through donations to find books worth selling on eBay and the steps taken to add, describe, and set a beginning auction price on eBay. He furnished useful information to those contemplating selling donations online and included a table of the average time it takes the volunteers to list items, correspond with buyers, and package and mail a book using eBay. According to his statistical analysis, the entire process takes 65.6 minutes per title. Hill admitted that selling books on eBay is labor-intensive and does not recommend online selling as an activity suited for salaried library staff. Still, the Friends group did earn $\$ 6,700$ by selling 167 books in eighteen months. Hill concluded "although time-consuming, selling unneeded books on 
eBay returns a steady stream of revenue to the library."

In the short case study, "Director, Do Thy Bidding," Rogers used a simulated conversation, based on actual events, between a public library director and an assistant library director to illustrate how a library is using eBay to both buy and sell materials for their collections. ${ }^{10}$ The director defended selling seldom-used archived items from its special collections in order to generate money to offset a small book budget. In response to this dialogue, two librarians, Gilmore and Weil, offered their analysis of a library procuring funds by selling online. Gilmore saluted online selling of unused library materials to bolster a budget. ${ }^{11}$ Weil agreed that online selling is a useful activity, but noted that-before selling library materials - a public library should consult with its collection development policies, the library board, the community at large, and other staff to ensure the procedures for sales are clear and that all agree with them. ${ }^{12}$

In Doylen's "Experiments in Deaccessioning: Archives and Online Auctions," the author discussed the "legal, ethical, and practical issues raised for archivists interested in using on-line auction sites to deaccession unwanted material." ${ }^{3}$ After assessing the legal and ethical implications, the collection management policies, and the procedure that an institution should consider before and after withdrawing materials from holdings, Doylen noted that "On-line auction sites provide archives with an innovative, expedient, and cost-effective means of selling unwanted items."14 Doylen drew on his own experience supervising a successful online selling program, describing in detail the auctioning of unwanted archival and special collections materials on eBay. In regard to a sensitive public relations issue so often affecting libraries, the author offered an encouraging summary, "initial concerns about negative public response to the sales lessened over the course of the experimental program. . . . The Archives received no negative responses to its selling program from the general public."15

Finally, two articles published on the rising used-book market are also worth notice. The first, "Online Usedbook Sales Concern Some Publishers," raised the concerns of the book publishing industry in the manner some book selling sites sell used books. ${ }^{16}$ According to some industry experts, commercial book selling sites, such as Amazon.com, list available used copies alongside the new editions, thereby offering customers cheaper alternatives. The fact that used books sales corner 15 percent of the 3.5 billion dollar book market shows the high stakes involved. ${ }^{17}$ The second piece, Brown's "The Used Book Market Grows," presented the results of several interesting studies performed on the used book market. ${ }^{18}$ In 2002, a study conducted by Ipsos Book Trends revealed that "consumers purchased more than 100 million used books worth half a billion dollars." ${ }^{\prime 9}$ An even more applicable study is one cited by Brown that published the results of survey responses received from more than 800 book sellers; this report noted that online sales account for half of all retail sales of used books. ${ }^{20}$

\section{Data Collection}

It is not uncommon to read messages on library electronic discussion groups and bulletin boards about the problems facing libraries as they dispose of unwanted gift and withdrawn materials. Librarians and library staff exchange experiences, tips, and policies on using book sales and book dealers to generate revenue while reducing stockpiles of gifts. In recent years, the subject of utilizing the Web to sell surplus materials has often become the focus of these discussions. Many of the postings have come from library staff who have little experience selling books online but are interested in pursuing this activity. Other messages originate from library staff with experience selling online, and, though the posted messages describe various obstacles and problems encountered, it is apparent some libraries are discovering that selling surplus materials online can be quite profitable.

To better understand the procedures and methods used by libraries selling online, the Smathers Library bookstore staff developed a brief questionnaire (see results in table 1) and sent it to representatives from two academic libraries with experience. The two libraries were the Engineering and Physical Sciences Library of the University of Maryland (EPSL) and the University of California, Riverside (UCR). Though both libraries are selling surplus materials online, they use different sites: EPSL uses Half.com, and UCR uses Alibris. Their responses permitted the Smathers Library Bookstore staff the chance to compare and contrast experiences with two online sites. The results of the questionnaire are interesting and reveal many positive aspects of selling online.

The questionnaire was sent to each library in spring 2003. EPSL had just started a yearlong pilot project to sell surplus books online. The results of the questionnaire are based on the respondent staff member's one-month experience managing the online selling at the library. ${ }^{21}$ A later e-mail message to a discussion group confirmed that after six months, EPSL's success with online selling was continuing. More than 170 books sold at approximately $\$ 24$ each, with a gross profit exceeding $\$ 4,800 .^{22}$ Offering a dual perspective, two librarians from UCR responded. The first was a librarian (now working at a different library) who managed online selling from the start up, the second was a librarian who has since taken over its management. Their response show that the success UCR had with online selling is continuing in a profitable and very organized man- 
ner; their feedback was incorporated into one composite response. ${ }^{23}$

The questionnaire explored libraries' procedures and experiences with online selling. The responses from the two libraries show pronounced similarities. Both libraries:

- sell only books;

- continue to hold book sales on campus;

- earn higher profits per book than what they receive in the book sales;

- use spreadsheets to record the books sold online;

- have inconsequential returns (one or none);

- attach basic "non-book dealer" descriptions for online listings; and

- rate their online selling experiences as very positive.

Additionally, both libraries take advantage of Half.com and Alibris offering "template" records that provide basic bibliographic information (that is, title, author, imprint information).

Another similarity between the two libraries and their experiences selling online is their positive responses to the question regarding the number of items sold and the average amount of each sale. In one month, EPSL grossed $\$ 755.76$ by selling twenty-six books at an average of $\$ 29.06$ per item. From December 2000 through March 2003, UCR grossed just more than $\$ 29,000$ by selling approximately sxity-nine books per month and averaged around \$15 per item. Also comparable is the staff time needed to list, record, and package books sold online. EPSL reported that managing online selling takes about threeand-a-half hours of staff time a week. According to the two librarians from UCR, after the initial eighty hours of staff time necessary to list their books in Alibris, between four and six hours per week were required to continue listing and selling books. Both libraries reported that the staff hours spent on managing the online selling were more than acceptable.

Excluding the length of time each library had been selling online (UCR for more than two years, EPSL for just one month), the differences between the two libraries' experiences are negligible. Because Alibris mandates that its sellers inventory several hundred books, UCR used eighty hours of staff time to list their books at the onset. EPSL, facing no such minimum requirements using Half.com, did not have to manage such an initial large block of staff time to list their books. While originally UCR did not have its organizational name appear in the books listed for sale through Alibris (the site did not require the seller to list their name), this policy has changed and "UC-R Regents" now appears in the listings. Half.com requires listing the book sellers, so EPSL uses an abbreviation that does not reflect back on the library or university.

\section{Alibris Selection Process}

At the American Library Association's 2003 Annual Conference, the Association for Collections \& Technical Services Acquisitions Section Gifts and Exchange Discussion Group offered a program on libraries and online book selling. ${ }^{24}$ At this informative roundtable discussion, representatives from Alibris and Abebooks made presentations summarizing their companies' operations. After a questionand-answer period, the vendors and audience participated in a roundtable discussion that shared information and experiences on the online selling of duplicate and unwanted library gifts.

eBay and its cousin, Half.com, both offer huge sales markets. Unfortunately, eBay and Half.com operate in a manner that creates serious obstacles for a library organization that reports to a state fiscal agency. One possible obstacle for state institutions arises from eBay and Half.com's policies requiring a seller to register using a credit card and subsequently

Table 1. Responses from other libraries selling books online

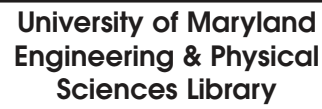

Months of experience selling books online at time Number of books sold

Gross sales

Average price per book

Length of time items listed online

Method used to track items in-house

Service used

List library's name online

Hours spent per week by library staff selling books online

Number of returned items

$$
\begin{array}{r}
1 \\
26 \\
\$ 755.76 \\
\$ 29.06 \\
\text { Until sold } \\
\text { Spreadsheet } \\
\text { Half.com } \\
\text { No } \\
2
\end{array}
$$$$
0
$$

\section{University of California- Riverside Library}

$$
\begin{array}{r}
28 \\
69 \text { per month (approx.) } \\
\$ 29,000.00 \\
\$ 15.00 \\
\text { Until sold; some weeding of poorer quality } \\
\text { books that do not sell } \\
\text { Spreadsheet } \\
\text { Alibris } \\
\text { Yes ("UC Regents") } \\
4-6(80 \text { hours initially to set up } \\
\text { minimum of 500 listings) }
\end{array}
$$


charging specified services and refunds to the holder of the card. Even though many state bureaucracies, including the University of Florida, permit the use of state issued credit cards or payment cards ( $\mathrm{p}$-cards), often state accountants closely monitor the $\mathrm{p}$ cards and severely restrict their use. The Smathers Library Business Office considered this credit card requirement a major deterrent in allowing the bookstore to use either eBay or Half.com. Another concern voiced by the library's business office was the manner in which the Smathers Library would receive payments from book buyers on eBay and Half. com. Both eBay and Half.com offer their buyers various methods for payment, including credit cards, checks, money orders, and an in-house credit card payment system called PayPal. Tracking such diversified payments would be very labor intensive and could present accounting problems with state auditors.

Alibris operates differently than eBay and Half.com and presents a more acceptable system for an academic state library. Presently, a seller must list a minimum of five hundred titles to be a certified book seller on Alibris, but the registration process is relatively fast, simple, and does not require the use of a credit card. Besides listing a seller's stock onsite, a seller's books listed on Alibris are searchable from other online retailer sites, such as Amazon and Barnes \& Noble. As items sell, Alibris monitors the sales and handles the payments from the buyer. At the end of every month, Alibris sends a check to the seller for all items sold during that period. Because Alibris acts as the brokering agent between buyer and seller, they deduct a 20 percent fee from the list price for each book sale. Working within this system, the seller avoids time-consuming correspondence or problems with buyers and receives payments consistently. Alibris also acts as the middleman for all returns. When a book buyer wishes to make a return for whatever reason, Alibris will handle the correspondence, return shipping of the item, and refund the buyer. For a seller, this system is very efficient and far less aggravating than having to deal with buyers and returns directly.

After reviewing the library literature, attending the Gifts and Exchange Discussion Group's program, and conducting a questionnaire, the staff determined that online selling could succeed at the Smathers Library Bookstore. Library administration agreed with this assessment and, in August 2003, gave approval to a one-year pilot project for selling books online. Based on discussions with representatives from Alibris, and from the favorable questionnaire responses received from the librarians at UCR, the bookstore staff chose to register the store as an Alibris seller.

\section{Listing Books Online}

Once registered on Alibris, book sellers obtain access to the site's Seller Hub with its in-house database system, Inventory Manager. The Inventory Manager database contains thousands of book records, and each record contains pertinent information regarding title, author, publisher, year of publication, edition, size of the text, and so on. To list a book for sale, the seller first searches the Inventory Manager to find the title and correct edition. If the exact record is located, the seller merely opens the "Add Item" template, updates bibliographic information, describes the condition, and prices the book. To simplify the process, Inventory Manager offers several pull down menus and check boxes for indicating whether a book is a signed copy, a first edition, and its general condition (fine, very good, good, and so on). Additional note fields are available for the seller to describe the book and dust jacket's condition in more detail. If the book is not found in the inventory, a blank template is provided for the seller to create original records. The staff estimates that more than 80 percent of the titles they search on Alibris have records in Inventory Manager, which saves considerable time.

Early into the online selling project, bookstore staff kept book descriptions short and nontechnical, but after time the bookstore staff gained confidence and began employing book market terms. Overuse of book trade jargon should be avoided (especially for untrained sellers); however, Alibris offers a helpful "Glossary of Book Terms" that the Smathers Library staff use frequently. ${ }^{25}$ As staff began applying more information and appropriate technical terms to book descriptions, the number of books sold each month more than doubled. In the first four months of the project, from September through December 2004, an average of less than eight books a month were sold on Alibris; in the next eight months of the project, from January through August 2005, an average of almost eighteen books a month were sold.

Pricing books (based on condition, description, and rarity) is another important consideration. In the early months of joining Alibris, the Inventory Manager included a free pop-up window with all the price listings for that title already in Alibris. This listing furnished a very helpful guide for pricing the book in hand, as the seller could base the price by other editions for sale. Unfortunately, a few months into the project Alibris began charging for this listing service. Rather than pay for this information, the staff began accessing book selling search sites (such as Bookfinder or Abebooks) to compare price and condition of the books. ${ }^{26}$ This added step of inputting a new search for the title on a separate browser in Bookfinder or Abebooks does slow down the process of pricing, but the staff consider this essential to 
setting a fair market price. Regardless of the increase in staff hours required to list online inventory in this manner, the staff attributes the steady rise in online sales to listing books with better prices and improved descriptions.

\section{Procedures and Staff Time}

During the project, the staff recorded the amount of time spent on procedures used for online book selling. Activities demanding the most staff time include describing and pricing the books, recording and shipping the sales, and monitoring the sales with a spreadsheet. After listing a book, the staff tags the record with a shelf number for tracking purposes. Once this tracking number is included, the record is printed and placed inside the book. Books for sale online are kept on several dozen shelves in a separate area away from the regular bookstore stock. Alibris sends notification by e-mail each time a book sells. Once notified, the staff pulls the book and carefully packages it with bubble wrap for mailing. Often the shipment is to the Alibris warehouse in Sparks, Nevada, where Alibris reroutes the book to the buyer; other times, the bookstore staff sends a book purchased directly to the buyer. For each online book sale, bookstore staff use an Excel spreadsheet to record the pertinent information, including Alibris' sale identification number and the title, author, and price of the book. The staff must also maintain the inventory within Alibris, removing items that sell, updating records, and printing mailing labels and invoices.

Another task is "preview searching," which is a term the staff uses when they conduct a quick scan on Bookfinder or Abebooks in order to determine a book's value in the online market. This preview searching takes only a couple minutes but it is crucial, as the value of individual books is not always obvious to the library staff. Going online to scout the used book market and compare the availability and prices on the used book market is extremely beneficial in deciding whether to sell the book online or in the Smathers Library Bookstore. After monitoring online sales, the staff set the cutoff line at $\$ 15$. If several copies of a book are being sold online or if most copies of a book are priced less than $\$ 15$ apiece, the staff considers selling online not to be worth the time and effort to do so.

In the first month of listing books, the average time required to place a book for online sale was approximately fifteen minutes, or four books per hour. With the bookstore staff working as a team for thirty-three hours a week, more than 130 staff hours during September 2003 were required to reach the five-hundredbook minimum requirement. Once the five-hundred-book requirement was met, staff spent six-and-a-half hours a week in the period October through December 2003 on online selling activities. For the next eight months of the project, January through August 2004 , the number of hours required of staff decreased to an average of six hours per week. (See table 2 for details on how staff time was spent.) Hours devoted to online selling decreased despite the fact that the most important and time-consuming task of listing books increased once staff began using Bookfinder and Abebooks to adjust prices and enhance book descriptions. The average time spent on listing a book increased from fifteen to almost twenty-five minutes per book; however, the overall average in staff time required per week decreased. This decline can be attributed to staff not only becoming more experienced at online book selling, but to improved in-house procedures over the life of the project.

\section{Conclusion}

The year-long online selling pilot project ended on September 1, 2004. It was an exciting experience for the entire staff of the Smathers Library Bookstore and a profitable enterprise for the library. In the proposal, the bookstore staff set the amount of $\$ 2,500$ as the sales goal. This target was reached after only seven months of selling books online; by the end of twelve months, 174 books had sold for more than $\$ 4,000$. Although the first month's sales were modest (six books sold for \$166), gross sales increased at a steady rate (see figure 1). In four months, online gross sales passed $\$ 1,000$, and, by the end of the first six months, sales were just less than $\$ 2,000$. After one year of online book selling with Alibris, gross sales totaled $\$ 5,932.45$. These gross earnings do not take into account Alibris' 20 percent

Table 2. Staff time devoted to online bookselling activities

\begin{tabular}{lcccc}
\hline Month & $\begin{array}{c}\text { \# Minutes Spent } \\
\text { Listing Each Book }\end{array}$ & $\begin{array}{c}\text { \# of Minutes Spent } \\
\text { Packing/Shipping Books }\end{array}$ & $\begin{array}{c}\text { \# of Minutes Spent on E-Mail/ } \\
\text { Spreadsheet and Database } \\
\text { Maintenance }\end{array}$ & $\begin{array}{c}\text { Average Staff Hours } \\
\text { Spent per Week }\end{array}$ \\
Sept. & 15 & 20 & 10 & 33 \\
Oct.-Dec. & 20 & 15 & 10 & 6.5 \\
Jan.-Aug. & 25 & 15 & 10 & 6
\end{tabular}


fee. After deducting Alibris' fee of $\$ 1,186.49$ (20 percent) from the year's gross, the library netted $\$ 4,725.46$ from its online book selling project (see table 3).

One stated goal of the proposal was to successfully balance online book selling with daily sales in the library bookstore, and in this regard, the results surpassed expectations. During the course of the yearlong online selling project, the Smathers Library Bookstore continued posting steady sales and actually brought in higher revenue than the previous year. In fiscal year 2003-2004, the Smathers Library Bookstore grossed $\$ 12,813.97$, versus $\$ 10,309.63$ in fiscal year 2002-2003. Included in the bookstore figures were individual sales to book dealers and, although sales with the dealers did drop overall (since a greater percentage of the finer-quality books were being sold online), the store's profits were not compromised.

In addition to boosting the library's general book acquisition fund by several thousand dollars, the staff learned a number of valuable lessons about the online selling of surplus books. The staff discovered that listing, describing, and pricing books is not as daunting a task as originally feared, due to the templates provided by the Alibris Inventory Manager and using the descriptions and prices found on book selling search sites, such as Bookfinder and Abebooks. The staff observed that, in general, books listed with more detailed information sell faster on Alibris, and learned the types of books that are better suited for selling online (books in construction, life sciences, and history) versus books that appeal to the browsing customer (art and cookbooks), which regularly sell faster in the bookstore.

As the project began, book returns were a major concern of the Smathers Library Bookstore. Whether due to conscientious book listing with accurate descriptions, luck, or a combination of both, only one return was needed in the project year. For whatever reason, the buyer changed his or her mind and decided to send the book back. Alibris handled this return very well and settled the request quickly and without problems. Since Alibris' policy is to send a monthly check to the seller for all sales (minus their fee), Alibris simply deducted the amount reimbursed for the return from the next monthly check issued to the Smathers Library.
Another factor to take into account with online book sales is the incidental costs incurred. Alibris does reimburse book sellers an approximated cost of postage for each book sale, but this reimbursement does not cover the costs of labels, padded envelopes, and packing materials (such as bubble wrap). Fortunately, Smathers Library can absorb these costs easily because packing materials are purchased in bulk. The staff estimate that

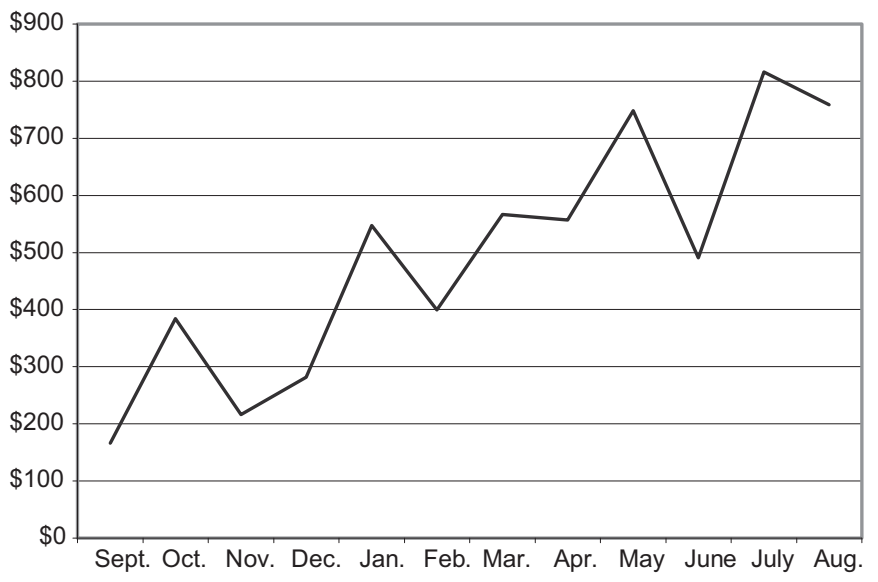

Figure 1. Gross online sales

Table 3. Online sales: September 1, 2003-August 31, 2004

\begin{tabular}{lccccc}
\hline \multicolumn{1}{c}{ Month } & $\begin{array}{c}\text { Gross Sales } \\
(\$)\end{array}$ & $\begin{array}{c}\text { Alibris Fee } \\
(\%)\end{array}$ & Net Sales (\$) & \# of Books Sold & $\begin{array}{c}\text { Avg. Sale Price } \\
\text { (Gross) (\$) }\end{array}$ \\
Sept. & 166.00 & -20 & 132.80 & 6 & 27.67 \\
Oct. & 384.00 & -20 & 307.20 & 10 & 38.40 \\
Nov. & 216.50 & -20 & 173.20 & 7 & 30.93 \\
Dec. & 281.50 & -20 & 225.20 & 8 & 35.19 \\
Jan. & 547.50 & -20 & 438.00 & 14 & 39.11 \\
Feb. & 399.50 & -20 & 319.60 & 11 & 36.32 \\
March & 567.00 & -20 & 453.60 & 17 & 33.35 \\
Apr. & 557.00 & -20 & 445.60 & 19 & 29.32 \\
May & 748.50 & -20 & 598.80 & 22 & 34.02 \\
June & 490.50 & -20 & 392.40 & 17 & 28.85 \\
July & 815.95 & -20 & 652.76 & 19 & 42.94 \\
Aug. & 758.50 & -20 & 606.80 & 24 & 31.60 \\
Totals & $5,932.45$ & $-20.50 *$ & $4,725.46$ & 174 & 34.09 \\
& & & & &
\end{tabular}

*One book returned. 
each book shipped costs the library $\$ 1.50$. During the year, the library bookstore sold, packaged, and shipped 174 books, costing the library approximately $\$ 260$. While this amount is not overwhelming, it may be significant for libraries with smaller budgets.

By the end of the pilot project, the staff realized that once they established an organized, efficient mechanism for online selling, the overhead and staff time needed for searching, pricing, listing, recordkeeping, and shipping orders is surprisingly low when compared to the revenue generated. However, this may or may not be true for other libraries attempting online sales. With the existence of a bookstore and a staff already familiar with procedures for the disposition of unselected gift materials and the tasks associated with selling books (pricing, bookkeeping and inventory maintenance), the Smathers Library has an ideal situation in place for selling books online. Other libraries may have a larger challenge and more hurdles to overcome in order to be successful. For the Smathers Library Bookstore, the pilot project accomplished its goal of balancing online and bookstore sales, and exceeded its expectations in revenue. As a result, library administration endorsed the continuation of online book selling.

\section{References}

1. George A. Smathers Libraries Collection Management Division, "Policy for Gifts of Materials," Collection Management Bulletin 6.15 (Dec. 14, 1994). Accessed Mar. 18, 2005, http://web.uflib.ufl.edu/cm/ manual/CMManual6-15.html.

2. University of Florida George A. Smathers Libraries Gifts and
Exchanges, "Information on Gift Donations." Accessed Mar. 18, 2005, www.uflib.ufl.edu/acqlic/ge/ Giftsrevised.htm.

3. University of Florida George A. Smathers Libraries Gifts and Exchanges, "Donor Registry for Gifts to the George A. Smathers Libraries." Access July 1, 2005, www.uflib.ufl. edu/acqlic/ge/Donor-Registry.htm.

4. For more information on the Smathers Library Bookstore, see Steven B. Carrico, "The University of Florida Smathers Library Bookstore," Library Collections, Acquisitions \& Technical Services 25, no. 1 (2001): 37-47.

5. See, for example, Vincent Golden, "Library Book Sales and Auctions, or, You Can Get More Than a Dollar for That!" in Gifts \& Exchanges: Problems, Frustrations, and Triumphs, ed. Catherine Denning, 143-63 (Binghamton, N.Y.: Haworth Pr., 1999); Nancy Barr, "An Amazing Bookstore," American Libraries 35, no. 1 (2004): 60-62.

6. Penny Schenker, "Book Sale Adds Internet Auction," The Unabashed Librarian 110 (1999): 24.

7. Kathleen A. Baxter, "Your Discards May Be Somebody's Treasure," Library Journal 125, no. 6 (2000): 62-63.

8. Dale S. Hill, "Selling Withdrawn and Gift Books on eBay: Does It Make Sense?" Journal of Interlibrary Loan, Document Delivery \& Information Supply 14, no. 2 (2003): 37-40.

9. Ibid., 40.

10. Michael Rogers, "Director, Do Thy Bidding," Library Journal 126, no. 6 (2001): 74-76.

11. Yolanda L. Gilmore, "Bravo Brodmerkel!” Library Journal 126, no. 6 (2001): 74-75.

12. Teri B. Weil, "Stick to Policy, Big D," Library Journal 126, no. 6 (2001): 76.

13. Michael Doylen, "Experiments in Deaccessioning: Archives and On-line
Auctions," The American Archivist 64 (Fall/Winter 2001): 350.

14. Ibid., 355 .

15. Ibid., 361

16. Bob Tedeschi, "Online Battle of Low-Cost Books," The New York Times, July 12, 2004. Accessed June 3, 2005, www.abebooks.com/docs/ CompanyInformation/PressRoom/ newYorkTimesJuly122004.pdf.

17. Ibid.

18. Scott Brown, "The Used Book Market Grows: An Inquiry Into the True Volume of Used Book Sales," OPMagazine 2, no. 4 (July/Aug. 2004), Accessed Mar. 18, 2005, www.finebooksmagazine.com/10-used-bookmarket.htm.

19. Ibid

20. Ibid.

21. Gloria L. Chawla, e-mail to the author, "About Online Book Selling," Mar. 13, 2003.

22. Charles Lowry, e-mail message to ARL-Directors Discussion List, “Book Sale Reprise," Nov. 19, 2003.

23. Pat Hilker, e-mail to author, "Online Book Selling," Apr. 24, 2003, and Pam Sun, e-mail to author, "Survey," Apr. 18, 2003.

24. "How to Liquidate Unwanted Library Materials in the Age of Double FoldAre Electronic Vendors the Answer?" American Library Association's Annual Conference, ALCTS Acquisitions Section, Gifts \& Exchange Discussion Group program. Speakers: Ross Viner, Abebooks, and Shelly Stuard, Alibris (Toronto, Canada: June 21, 2003).

25. Alibris, "Glossary of Book Terms." Accessed Mar. 18, 2005, www.alibris. com/glossary/glossary.cfm.

26. Bookfinder.com, "The Open Marketplace for Books Online." Accessed Mar. 18, 2005, www.bookfinder.com. Abebooks.com, "Because You Read.” Accessed Mar. 18, 2005, www.abebooks.com. 